\title{
After Governance: A Normative Reflection on Civil Society Participation in Policy Processes
}

\author{
Acar Kutay \\ Postdoctoral Fellow, Department of Political Science, Lund University
}

Er det muligt for nationalstater at understøtte civilsamfundsorganisationer økonomisk, uden at civilsamfundet samtidig mister sin kritiske distance til staten? I denne artikel undersøger post.doc. Acar Kutay de normative implikationer, der følger af at integrere civilsamfundet i nye former for politisk styring. Artiklen fokuserer særligt på økonomiske bevillinger og disses implikationer for civilsamfundets autenticitet og autonomi. Artiklens overordnede argument er, at øget integration har medført en teknokratisering og professionalisering af civilsamfundet, som i sidste ende slører den funktionelle opdeling mellem stat, marked og civilsamfund.

\section{Introduction}

Most scholars view the recent massive increase in the number of non-governmental organisations (NGOs), or civil society organisations (CSOs) across the globe as a sign of positive civil society development. CSOs are considered an important component of democratisation; engagement in CSOs, so the traditional narrative goes, can help citizens participate more effectively in the selfgovernance of their societies and restrict the excesses of the state and the business/corporate sector (Kaldor 2005; Edwards 2004; Anheier 2004). However, I apply a critical approach in this paper to the dominant opinion that the increase in CSOs and the increased influence of pragmatic governance in CSOs is by definition a positive de- velopment. I am interested in the normative implications of pragmatic governance as it currently affects civil society and also explore the effects of managerial thinking on the emergence of new actors in civil society.

Pragmatic governance refers to recent changes in public administration and policy making. It has brought about the weakening of the state by the devolution of its responsibilities among non-state actors and has aimed to execute non-ideological politics. It prioritises the outcomes of policy making and administration over politics. Managerialism, on the other hand, suggests an organising principle for society, and an ideology, that implies that any type of organisation (the state, corporations, NGOs, and even supermarkets) should be managed according to the same type of management principles, policies, and tasks.

First, the traditional, dominant normative view of civil society relies on a particular (liberal) conception of civil society that was first articulated by the $19^{\text {th }}$ century political thinker Alexis de Tocqueville. De Toqueville's observations of civic associations in the America of the 1830 s and 1840s describe what we now call civil society as autonomous, i.e. independent of the state, and composed of spontaneous and voluntary organisations.

However, the beginnings of civil society that de Tocqueville observed have evolved over time to a very different type of organisation. Today, CSOs are often imposed upon societies that have no history of spontaneous association with the deliberate political intention to create a civil society where it does not exist. Moreover, there has been an increasing incorporation of some CSOs into pragmatic governance settings that exhibit techno- 
cratic and managerial tendencies that do not reflect our original idea of how civil society emerges in a society and by what norms they operate. In fact, this re-defining of the normative ideas and the functioning of civil society constitutes nothing short of a revolution in their role in any given society.

What is more, pragmatic governance opens up decision-making processes to non-state actors, including civil society, that have been the traditional domain of the governance sector. The traditional approach of civil society does not support such practice: these associations have long been considered important for democracy because they create and strengthen civic bonds in a given community and act as a counterpoint to the state (Putnam 1993; Habermas 1992; 1996). In other words, not only is the de Tocquevellian view of civil society incompatible with pragmatic governance, it is arguably now counter-factual.

Second, we need to rethink the traditional liberal approach that defines the state, the economy and civil society as autonomous entities, or as domains that are structurally differentiated from each other. This is particularly true when non-state actors such as CSOs share political power by taking responsibility for public administration and governing. The meshing of the technocratic style of policy making and managerial organisation with the new pragmatic governance also blurs the distinction among state, economic and civil society actors because each of these actors in this new arrangement is administered by common organisational values, norms, and goals.

Third, the procedures and formal structures through which civil society has been integrated into the institutional settings of governance may foster the formation of new managerial actors within civil society who are willing and able to take part in the governance of society. This means that CSOs now engaged in pragmatic governance are not representative of an authentic or autonomous civil society.

In this paper, I discuss the implications of pragmatic governance and managerial thinking and practices for civil society. The first section provides an overview of the associational revolution in recent years and evaluates the strategy of involving NGOs in pragmatic governance. The second section examines the implications of the procedures and formal structures through which civil society has been integrated into the institutional settings of governance. The third section reflects upon the general effects of managerialism and pragmatic governance on civil society.

\section{Context and normative theory}

Since the 1990s, we have witnessed a massive growth of NGOs both in the global South and the North, a histo- rical moment that has been described as an 'associational revolution' (Salamon 1994). Relying on the documentation of Lang $(2012,13)$, '[n] ational surveys have counted more than one million NGOs in India (Sooryamoorthy and Gangrage 2001), 359,000 registered in Russia (Skvortsova 2007), 55,000 in Poland (Garzstecki 2006), 570,000 in Germany in 2008 (DGVM 2007; Vereinsstatistisk 2008), and 161,000 in Canada (Statistics Canada 2005)'. Most of these associations have not emerged spontaneously, and many depend on external funding from government, bilateral aid agencies working in international development, international organisations (World Bank, United Nations), the European Union (EU), and political and private foundations (Reimann 2006, 48; Salamon 2010; Swyngedouw 2005). An expert on the role of this NGO funding boom suggests, 'It is impossible to understand the explosive growth of NGOs in the past several decades without taking into account the ways in which states, international organisations, and other structures have actively stimulated and promoted NGOs from above' (Reimann 2006, 46 ). This process is also occurring in the US, whose political system is based on the liberal policy of non-intervention in civil society (Salamon 1995).

Non-profit organisations that focus on delivery of services have been supported largely by governments and other foundations in recent decades (Reimann 2006; Walker 1991; Berry 1999). Reimann (2006, 48) calculates that since the late 1990s, an average of \$6-8 million per year was transferred from the West to the South with the political intention of improving civil society. In 2009 alone, the European Commission spent $€ 1.4$ billion on approximately 300 CSOs (European Parliament 2010; Salgado-Sanchez 2014; Mahoney and Beckstrand 2011).

Some commentators suggest that the simultaneous 'appearance' of the associational revolution, pragmatic governance and the entrenchment of neoliberal hegemony might not be a mere coincidence. Because pragmatic governance depends on external contributions to policy making processes and the delivery of services (particularly in health and education), NGOs are now encouraged to become involved as partners and contractors within new governance constellations. As such, NGOs and other non-state actors are taking over some of the roles of the state, thus weakening or dismantling the hierarchical bureaucracy and the state's involvement in economic and social governance. In that sense, pragmatic governance has largely aligned with neoliberalism (Bevir 2010): it is helping to hollow-out the state and sharing its core functions among non-state actors.

The literature cited here discusses a number of different issues related to NGOs, including the perils of 
exporting a Western model of state-society to the South (Mercer 2002) and reinforcing neoliberal policies (privatisation of the public sector, structural adjustment policies) under the rallying cry of democracy promotion in Central and Eastern Europe (della Porta 2014) and Latin America (Leal 2007). Observers of the proliferation of associations also express concern about socially embedding neoliberal capital accumulation by including a third sector in governance (Porter and Craig 2004) and invoking associations as a new form of governmentality (Fyfe 2005; Morrison 2000; Kutay 2014). Some commentators even consider the participation discourse about the necessity to engage civil society in governing a 'new ideology' (Cooke and Kothari 2001).

This paper contributes to the literature on the NGO boom critically, and from a normative perspective. I submit that pragmatic governance is clearly aligned with the neoliberal project, and that the potential of civil society to legitimise government is threatened when the state and the economic sector expand into its sphere. Moreover, the traditional separation of the public and private is blurred when these organisations engage in public administration or delivery of services (Lang 2014; Morrison 2000). This trend compels us to question the third sector approach to governance and the prevailing conception of civil society today compared to the conception originally inspired by de Tocqueville.

The following section evaluates the political aim to create civil society and to integrate some CSOs into governance settings. It suggests that the normative view of civil society as associational and autonomous is now counter-factual, or at the least limited under governance settings.

\section{Pragmatic governance is not a system of governance}

Normative approaches to CSOs conceive them as principal agents of participatory democracy (Gaventa 2004), as institutional venues for the promotion of identity and democratic values (Putnam 1993, Calhoun 1993), and as a 'transmission belt' between the citizenry and policy making processes (Nanz and Steffek 2004). A well-functioning civil society is considered an important element of democratic legitimacy. But to what extent does participation of CSOs in governance follow normative theory, or are both normative and governance approaches informed by the same understanding and ontology of civil society?

The argument is straightforward: if a normative view does not support the practice of the political intervention in civil society and their involvement in governance, then the current CSO participation under new governance settings runs counter to the established norms. The concomitant argument is a more complicated one: if the social conditions which inform the normative theory have changed, then we should reconsider our conception of civil society.

Given the widespread belief that ideological politics and representational democracy have proven inadequate to the management of contemporary governing issues, a pragmatic approach to governance and post-ideological ambitions is conceived by both scholars and NGOs as a rescue plan for democratic legitimacy. By adapting a functional approach to civic participation, pragmatic governance defines NGOs as legitimate according to their ability to contribute to solving common societal problems effectively by sharing the traditional responsibilities of the state (Salgado-Sanchez 2014; Anheier 2004). Pragmatic governance implies that social issues can be fixed by technical intervention and expertise and practiced through technocratic knowledge and often by evidencebased policy (EBP). (EBP suggests that public policy and decision making should be accompanied by scientific evidence, or at the least by some form of evidence.) In pragmatic governance, participation, too, is considered evidence; such a conception of participation aims to go beyond ideology by reflecting the 'real' interests of the people (Head 2008).

The problem here is that pragmatic governance blurs the division of labour between the state and civil society. It leads to the de-politicisation of civic activism and stigmatises social conflicts and differences of opinion by ruling out, or actively discouraging, threatening and less predictable modes of social action like protests, informal gatherings, or spontaneous reactions (Leal 2007). On the whole, different interpretations of pragmatic governance such as 'good governance' and the 'third sector approach' rely on the view that civil society is inherently autonomous and 'good' when compared to the state. Yet, this view seems to stem more from hostility towards the state, which is associated with ineffectiveness, corruption, and use of power, than from intrinsic features of civil society. This point will be further expanded below.

\section{Evaluation of pragmatic governance}

Pragmatic governance conflicts with another type of functional approach to governance that adopts a more sociological and systemic understanding and relates civil society to structural-functionalism (Kohler-Koch and Finke 2007; Kohler-Koch 2010; cf. Kooiman 1993). In this view, organisations derived from civil society are established to generate norms and values that democratise the system of governance. This democratising function of CSOs is a critical one because economic and political power, with their inner logic that prioritises instrumental and strategic rationalities (Habermas 1987; Baccaro 
2006; Kohler-Koch and Finke 2007), cannot provide democratising norms and values (Habermas 1987; Baccaro 2006; Kohler-Koch and Finke 2007).

Both normative approaches to civil society and the systemic approach to governance find their inspiration in the ideas of Jurgen Habermas (1996) when they connect civil society discourses to political and public spheres. Habermas (1996) suggests that what makes a political system democratic is the transmission of discourses that emerge from within the 'life-world' of society and enter the decision- and law-making structures of the political sector. However, Habermas (1996; 1992) does not suggest transmitting discourses generated from within civil society to the decision-making structures of civil society itself. In his model, this task is realised by elections, political parties, and the media.

Therefore, Habermas's discourse ethics is not compatible with, nor can it be stretched to fit pragmatic governance. In his view, particular interests advocated by social actors legitimise public policies if and when these interests express an all-encompassing or systemic understanding of democracy. Similarly, democratic procedures and principles must be practised by CSOs in order for civil society to realise its potential. From the viewpoint of deliberative democracy (Habermas 1996; Benhabib 1994), associations generate public deliberations, but these deliberations are understood as either 'without specific actors' or 'anonymous' public conversations.

Habermas is also sceptical about the bureaucratisation of civil society and the imposition of economic 'logic' on CSOs when the bureaucratic mentality and economic values dominate civil society. Under these circumstances, Habermas (1987) argues, the life-world of civil society is colonised. However, the term colonisation cannot be restricted to actions of political institutions alone. Managerial norms and practices are formulated by and can emerge from disparate fields and circulate through an assemblage of actors, including think tanks, universities, and private consultancy agencies and can be used very effectively as the means by which the norms and values of an ideal civil society can be compromised.

The colonisation of civil society also distorts the aforementioned structural differentiation of the state, economy, and civil society. Traditional structural differentiation requires that each domain functions in terms of its own internal 'logic'. But bureaucratic mentality and economic norms are extrinsic to civil society because they originate and infiltrate civil society from without. They are extrinsic because bureaucracy detaches the means of social action from their ends, while the economy is grounded on the principle of cost-benefit calculation. Neither of these organising principles is authentic to ci- vil society, which is presupposed to be the domain of communicative action.

CSO participation in governance is considered to be a way to politicise governance by balancing the influence of business interests (Kaldor 2005; Keane 2009: SalgadoSanchez 2014 344). Paradoxically, the means of politicisation - civil society - has, in fact, been shaped by and incorporated into governance settings in a depoliticised vein. However, de-politicisation eliminates the possibility for contention, resistance, and critique that could emerge from within society. Thus construed, depoliticised participation directs (or re-moralises) the interests of CSOs towards the norms and values of neo-liberalism and managerialism.

As some commentators have observed, some CSOs even integrate into the power structures of their governments. One of the reasons for the emerging 'partnership' of NGOs and power groups is the entitlement of status. In governance, status is conferred upon stakeholders, although as Erik Swyngedouw observes, the notion of stakeholder is 'necessarily constrained and limited in terms of who can, is, or will be allowed to participate' (Swyngedouw 2005, 2000). The conferring of stakeholder status contains an authoritative element that identifies governance participants:

[l]n most cases, entitlements are conferred
upon participants by those who already hold
a certain power or status. Of course, the
degree to which mobilisations of this kind are
successful depends, inter alia, on the degree
of force and/or power such groups or
individuals can garner and on the willingness
of the existing participants to agree to include
them (Swygedouw, 2005, 2000).

Thus, governance settings restrict the privilege of status as a governance participant and all-important funding to certain groups. Fierce competition to obtain funding, become a stakeholder, achieve status, and fit into the institutional environment fosters an institutional Darwinism: in a managerial environment only the fittest among the institutions can survive (Jessop 2007, 193). In this case, being fit is about the ability to meet the requirements of the governance system (e.g., running an organisation, performing bureaucratic and reporting functions, and negotiating with other stakeholders). This implies that only organisations willing to play the game according to the rules remain within the institutional milieu.

This 'selection process' may be unavoidable because it is impossible to financially support and integrate all groups into governance. The question here is the ground 
on which such exclusion rests, i.e. which groups or what kind of civil society subjectivity is considered to be more compatible with governance. Not surprisingly, the voices of contentious and non-professional groups are excluded. Such exclusion is a moralising and constitutive political act because it both defines and constitutes suitable civil society actors for governance settings. In other words, pragmatic governance does not envisage civil society as an authentic and autonomous realm.

Consequently, if civil society is to be understood as an autonomous domain, and if its authenticity is to be derived from reflexivity and communicative action, we must look for alternative ways to study the legitimacy of pragmatic governance as practised in CSOs. Under pragmatic governance, both the autonomy and authenticity of civil society are distorted, and the various institutions of government, the private sector, and civil society generally share the same norms, values and practices. Pragmatic governance also restricts the generation of authentic reason - reason that is not distorted by the economic sector or by bureaucracy - from within the 'participating' civil society. The new actors in civil society who are promoted by pragmatic governance can be seen as part of the technocracy, in the view of Habermas, as constituent of a historic bloc or organic intellectuals, in the view of Gramsci, and as disciplined by the power of discourse, in the view of Foucault.

Even more tellingly, pragmatic governance leaves a narrow space for CSOs to reinforce social progress. Limiting the function of CSOs as effective problem-solving actors, pragmatic governance construes the relationship between civil society and governance as one of domination, and occludes any opportunity for the emanation of communicative rationality, counter-hegemony, or the liberty to deny the requirements imposed by political rationalities.

Let us consider the way in which civil society is conceptualised in critical theory. For Habermas (1987), civil society is the space in which the 'communicative rationality', as opposed to economic and bureaucratic rationalities, flourish. For Gramsci (1971), civil society is the space in which counter-hegemony is built. Foucault (2009) argues that counter-conducts, i.e. alternatives to hegemonic views on how to guide our social life and behaviours, emerge from civil society. If 'critique' is understood as the 'art of discerning', as generating an alternative way of reasoning or of doing things, and as detaching from views that are taken for granted in any given institution, CSOs participating in the governance system have limited space in which to be critical because of the very nature of the policy making processes and political patronage.
In a systemic understanding of governance, civil society is supposed to be involved in governance as both an autonomous and authentic domain. But the norms and practices of pragmatic governance and the attempts of disparate actors to create managers out of civic activists run counter to that understanding. In pragmatic governance, civil society is not considered as being a preexisting domain that is waiting to be incorporated into the system of governance. Conversely, it is conceived as a domain constituted by actors that are becoming compatible to pragmatic governance. Effective problem-solving in pragmatic government necessitates adopting expert skills and efficient management structures and adapting to professional communication techniques in order to create better impact assessments. ${ }^{1}$ Master's degrees are often preferred to a record of traditional grassroots activism, particularly in policy making processes, and managerialism requires CSOs to think and act like bureaucrats and to adapt to a technocratic and bureaucratic culture that is very different from that of civil society.

\section{New civil society actors for the new era?}

How does pragmatic governance restrict and constitute civil society? Why should we consider NGOs engaged in pragmatic governance as new civil society actors? As part of my response to these questions, I argued above that because pragmatic governance prefers willing and capable actors and aims to detach politics from administration, CSOs engaged in governance are expected to act in a de-politicised manner. Yet, the de-politicisation and professionalisation of civil society are heightened by another social process that has been coupled with pragmatic governance: managerialism. This term refers to the domination of the idea that social issues can be more efficiently organised and governed by professionally educated managers. For example, consider business school graduates, who are trained to manage any kind of organisation by the special expertise of managing. This approach is now connected to New Public Management, whose managerial norms and practices are now moving from the corporate sector to public institutions and civil society.

As recent empirical research has shown, managerialism has been disseminated globally among NGOs since the 1980s and influences 'even the smallest NGOs' (Roberts et al. 2005, 1849; Salamon 2010; Skocpol 2003; Eikenberry and Kluver 2004). Managerial norms and practices, namely project cycle management and logical frame analyses, were first developed by the United States Agency for International Development (USAID). They are now commonly used by institutions supporting NGOs in developing countries for both effective project 
management and accountability reasons (Roberts, Jones III and Fröhling 2005). ${ }^{2}$ They are also intended to shape the structure of these organisations: even the way NGOs communicate with the public and other stakeholders by reports, newsletters, webpages, and position papers are subject to these managerial techniques.

Different disciplines have outlined various negative consequences of managerialism, including critical management (Parker 2002), governmentalisation of civil society (Morrison 2000; MacKinnon 2000), and the replacement of voluntary spirit in CSOs with a management mentality (Skocpol 2003). Managerialism is transforming social activists into problem-solving managers. It also hinders the development of civic bonds and community building, which are thought to be intrinsic to the ideal concept of civil society (Skocpol 2003). Furthermore, managerialism is understood as management of any kind of institution that operates by rules and assumptions regardless of who or what is being managed (Burnham 1942; Parker 2002). By applying similar management skills to all areas of social concern, managerialism also restricts creativity and the potential for the emergence of communicative rationalities (Parker 2002).

Unfortunately, I cannot expand this important issue here due to the pressure of space, but readers might wish to visit the rich corpus of literature on this theme. In the following section, I now focus on at least four effects of the implementation of managerial knowledge and practices on NGOs.

\section{What does pragmatic governance and manageria- lism do to civil society?}

Pragmatic governance not only rationalises, but also justifies, normalises, and moralises managerialism in social action. This is how pragmatic governance directs the interests and desires of people.

First, pragmatic governance is not solely a concern of political institutions - it also concerns the ethics of the self. It intertwines the governance of the self (as an active and responsible citizen), collective action (as results-based and results-oriented stakeholders who do not engage in contentious social conflict or activism), and governance models (as evidence- and activity-based management).

Second, pragmatic governance and managerialism have implications for the moral foundations of society. Both treat discourses of social movements, such as the values of equality, solidarity, environmentalism, and human rights, not as ends in their own right. They do so by reinforcing a universal organisational and rationalisation framework for all kinds of social discourses (Robert et al 2005; Srinivas 2009). This type of management fra- mework prioritises know-how, and privileges form over the content.

The domination of managerial understanding in civil society leads to the normalisation of instrumental rationalities, or the cost-benefit approach to solving problems of the society. Kalberg argues that this normalisation is applied 'to the degree that sheer calculation in terms of abstract rule reigns, decisions are arrived at „without regard to persons“" (Kalberg 1980, 1158; see also Parker 2002). Yet, this runs counter to the normative perspective that conceives organised civic action intrinsically as embodying a rationality that is political, i.e. one that represents public reason and thus reinforces social progress (Kaldor 2005). A consequentialist view of civil society also conflicts with the view that finds the merits of association within the associational life itself. In critical theory, civil society is not restricted to a utilitarian vision that aims merely producing effective policies in order to satisfy the happiness of everyone.

Third, pragmatic governance and managerial practices make control and auditing possible. They aim to translate the activities of CSOs (goals, outcomes, results, and outputs) to calculable and measurable performance indicators by virtue of advancing models that specify how to quantify actions of CSOs. Numbers also make auditing and the control of CSOs easier and less costly (Power 1999). The strong emphasis on performance as the consequence of action, however, suggests that ideas or values that are not represented, or that cannot be represented as performance, are either empty or nonsensical (Power 1999).

For example, when a managerial approach is applied to NGO management, the ideas of the NGO are valid only to the extent that they can be translated into or represented in a tangible form, such as policy suggestions, reports, or communication tools. This is problematic, since such a managerial approach reduces common good and civic discourses to a matter of utilitarian ethics. However, the merits of common good and civic values cannot be assessed in accordance with consequentialist criteria - they have merits in their own right. For instance, a social movement protesting the building of a nuclear plant does not require professional organisational knowledge or management based upon technocratic business approaches. The same is true for groups such as human right organisations, gender groups, and social groups that advocate the common good and aim to transform power structures. Of course, this claim does not imply that civil society actors or social movements should obviate any kind of organisation and operate spontaneously at all times. The point is that one must question the emphasis on cost-benefit approaches ('instrumental 
rationalities') and find alternative ways of organising without having to implement managerialism and business approaches - they are not our destiny, they are a choice. It is fair to say that critical management studies have focused seriously on advancing such alternatives, such as promoting non-elitist and democratic organisations in order to counteract managerialism. In order to research these issues constructively, future studies could identify those alternatives and discuss their potential.

Fourth, the involvement of CSOs in pragmatic governance may reinforce the status quo or legitimise socially unacceptable public policies. This is all the more serious because managerial norms and practices rely primarily on consequentialist ethics: they aim to legitimise the social purposes of organisations in terms of the outcomes of their actions, in this case, effective problem-solving. Such a view suggests that we are supposed to judge the merits of participatory governance merely in terms of its outcomes, or consequences, which detaches the practice (managerial governance) from action (problem-solving).

However, outcomes alone cannot hold any purpose; they are not independent from the practices. Morally speaking, it would be more appropriate to suggest that purposes should determine outcomes because organisational outcomes are neither neutral nor apolitical in nature. Otherwise, from a Marxian perspective, the exchange value of managerial participation in pragmatic governance (consultancy, the symbolic use of participation and the prevalence of public relations technologies) dominates the traditional use value, or purpose, of civil society - i.e. restraining power, channeling public discourse, and reinforcing progressive social change. This argument implies that the methodology of social action (i.e. ways of doing things) and the ontology of social activism (i.e. social issues that call for the mobilisation of social action) are never neutral or apolitical; in this case, they are shaped and restricted by managerialism and neoliberalism, respectively.

\section{Conclusion}

In this paper I focus on the implications of pragmatic governance and the spread of managerial norms and practices globally among NGOs. I argue that pragmatic governance runs counter to the traditional approaches of civil society. It requires civil society actors, i.e. CSOs, that are compatible with the technocratic and managerial style of decision-making. However, I am not suggesting that political institutions are by nature 'evil' because they distort a well-functioning civil society, or that CSOs are mere orbits of political power. Both political and civil society actors are subject to the same social process, which de-configures and re-configures the boundaries between them under pragmatic governance and managerial thinking. If neoliberal governance and managerial formations are the 'new reality', participation of civil society in governance might be considered a 'false activity', because such participation does not result in progressive social change and, in fact, reinforces the status quo.

The aim of this paper is not convince the reader that all public funding of CSOs is useless and wrong and should be suspended. Nor does it imply that all actions of CSOs are meaningless and that NGOs should be eliminated. Governments and donor institutions might use funding to create new venues for their programmes and ideological projects, and some CSOs might be willing to be instruments of political institutions in order to realise their goals. But we need to address the entangled processes of technocratic policy making and managerialism that now inform, restrict, and constitute both political institutions and civil society. 


\section{References}

Anheier, H 2004, 'Third sector-third way: comparative perspectives and policy reflections', in J Lewis \& R Surrender (eds), Welfare state change: towards a third way?, Oxford University Press, Oxford, pp. 111-135.

Baccaro, L 2006, 'Civil society meets the state: towards associational democracy?', Socio-Economic Review, vol. 4, no. 2, pp. 185-208.

Benhabib, S 1994, 'Deliberative Rationality and Models of Democratic Legitimacy', Constellations, vol.1, no.1, pp.26-52.

Berry,J. M 1999, 'The Rise of Citizen Groups', in Civic Engagement in American Democracy, T Skocpol \& M Fiorina (eds.), Brookings Institution Press and Russell Sage Foundation, Washington.

Bevir, M 2010, Democratic governance, Princeton University Press, Princeton.

Burnham, J 1942, The managerial revolution, Penguin Books, Hammondsworth.

Calhoun, C1993, 'Civil society and the public sphere', Public Culture, vol. 5, no. 2, pp. 267-280.

Cooke, B \& Kothari, U 2001, Participation: the new tyranny?, Zed Books, London.

Della Porta, D 2014, 'Democratization from below: civil society versus social movements?', in T Beichelt, I Hahn, F Schimmelfenning \& S Worscech (eds.), Civil Society and Democracy Promotion, Palgrave Macmillan, Basingstoke. pp. 137-149.

Deutsche Gesellschaft fur “ Verbandsmanagement (DGVM) 2007, 'Verbandestatistik', http://www.verbaende.com/ 8 AF9F995EF0B47D09BFFD7ED8E7244C0.htm (accessed 1 March 2009).

Edwards, M 2004, Civil Society, Polity, Cambridge.

Eikenberry, AM \& Kluver, JD 2004, 'The marketization of the nonprofit sector: civil society at risk?', Public Administration Review, vol. 64, no. 2, pp. 132-140.

European Parliament 2010, Financing of Non-governmental Organizations (NGO) from the EU Budget: European Parliament, Brussels.

European Commission 2004, Project Cycle Management Guidelines, EuropeAid Cooperation Office, http://ec.europa.eu/europeaid/ how/delivering-aid/project-approach/index_en.htm. (Accessed 11 May 2012).

Foucault, M 2009, Security, Territory, Population: Lectures at the College de France 1977-1978, Michel Senellart (ed), Palgrave MacMillan, Hampshire and NY.

Fyfe, NR 2005, 'Making space for „neo-communitarianism“? The third sector, state and civil society in the UK, Antipode, vol. 37, no. 3, pp. 536-557.

Garsztecki, S 2006, 'Zivilgesellshaft in Polen', Polen News, http: //www. polen-news.de/puw/puw-83-07-html (Accessed 3 January 2009).

Gaventa, J 2004, 'Towards participatory governance: assessing the transformative possibilities', in S Hickey\& G Mohan (eds), Participation: from tyranny to transformation: exploring new approaches to participation in development, Zed Books, London, pp. 25-41.

Gramsci, A 1971, Selections from the Prison Notebook, Lawrence and Wishart, London.

Habermas, J 1987, The Theory of Communicative Action, Volume 2: Lifeworld and System: A Critique of Functionalist Reason, Beacon Press, Boston.

Habermas, J 1996, Between Facts and Norms. Contributions to a Discourse Theory of Law, MIT Press, Cambridge MA.

Habermas, J 1992, 'Further Reflections on Public Sphere', in C. Calhoun (ed), Habermas and the Public Sphere, MIT Press, Cambridge: MA, pp. 421-462.

Head, BW 2008, 'Three Lenses of Evidence-Based Policy', Australian Journal of Public Administration, vol. 67, pp. 1-11.
Jessop, B 2007, State power: a strategic-relational approach, Polity, Cambridge.

Kalberg, S 1980, 'Max Weber's Types of Rationality: Cornerstones for the Analysis of Rationalization Processes in History', The American Journal of Sociology, vol. 85, no. 5, pp. 1145-1179.

Kaldor, M 2005, 'The idea of global civil society', in G Baker \& D Chandler (eds), Global civil society: contested futures, Routledge, New York, pp. 103-112.

Keane, J 2009, The Life and Death of Democracy, Simon \& Schuster, London.

Kochler-Koch, B and Finke, B 2007, 'The Institutional Shaping of EUSociety Relations: A Contribution to Democracy via Participation?', Journal of Civil Society, vol.3, no.3, pp. 205-21.

Kochler-Koch, B 2010, 'Civil society and EU democracy: „Astroturf“ representation?'. Journal of European Public Policy, vol. 17, pp. $100-116$

Kooiman, J 1993, Modern Governance, New Government-Society Interactions, Sage, London.

Kutay, A 2014, 'Managerial formations and coupling among the state, the market, and civil society: an emerging effect of governance', Critical Policy Studies, vol. 8, no. 3, pp. 247-265.

Lang, S 2012, NGOs, Civil Society, and the Public Sphere, Cambridge University Press, Cambridge.

Leal, A 2007, 'Participation: The Ascendancy of a Buzzword in the NeoLiberal Era', Development in Practice, vol. 17, no. (4/5), pp. 539-548.

MacKinnon, D 2000, 'Managerialism, governmentality and the state: a neo-Foucauldian approach to local economic governance', Political Geography,vol. 19, pp.293-314.

Mahoney, C and Beckstrand, M 2011, 'Following the Money: European Union Funding of Civil Society Organizations', Journal of Common Market Studies, vol. 49, no. 6, pp. 1339-61.

Mercer, C 2002, 'NGOs, civil society and democratization in the developing world: a critical review of the literature', Progress in Development Studies, vol. 2, no. 1, pp. 5-22.

Milani, CRS 2009, 'Evidence-Based Policy Research: Critical Review of Some International Programmes on Relationships between Social Science Research and Policy-Making', UNESCO, Paris.

Morrison, J 2000, 'The government-voluntary sector compacts: governance, governmentality, and Civil Society', Journal of Law and Society, vol. 27, no.1, pp. 98-132.

Nanz, P and Steffek J 2004, 'Global governance, participation and the public sphere', Government and Opposition, vol. 39, pp. 314-335.

Parker, M 2002, Against management, Polity, Cambridge.

Porter, D and Craig, D 2004, "The third way and the third world: poverty reduction and social inclusion in the rise of 'inclusive' liberalism', Review of International Political Economy, vol.11, no. 2, pp. 387-423.

Power, M 1999, The audit society: Rituals of verification, Oxford University Press, Oxford.

Putnam, R 1993, Making Democracy Work: Civic Traditions in Modern Italy, Princeton University Press, Princeton.

Reimann, KD 2006, 'A view from the top: International politics, norms and the worldwide growth of NGOs', International Studies Quarterly, vol. 50, no.1, pp. 45-68.

Roberts, SM, Jones III, JP, and Frohling, O 2005, 'NGOs and the Globalization of Managerialism', World Development, vol. 33, no. 11, pp.1845-1864.

Salamon, LM 1995, Partners in Public Service, Government-Nonprofit Relations in the Modern Welfare State, Johns Hopkins University Press, Baltimore. 
Salamon, LM 2010, 'Putting the civil society sector on the economic map of the world', Annals of Public and Cooperative Economics, vol. 81, no. 2, pp. 167-210.

Salamon, LM 1994). 'The rise of the nonprofit sector', Foreign Affairs, 109-122.

Sanchez-Salgado, R 2014, 'Rebalancing EU Interest Representation? Associative Democracy and EU Funding of Civil Society Organizations', Journal of Common Market Studies, vol. 52, no. 2, pp. 337-353.

Skocpol, T 2003, Diminished democracy: from membership to management in American civic life, University of Oklahoma Press, Norman.

Srinivas, N 2009, 'Against NGOs? A critical perspective on nongovernmental action', Nonprofit and Voluntary Sector Quarterly, vol. 38. no. 4, pp. 614-626.

Skvorsta, A 2007, 'NGOs in Russia. Information and Analyses Center for Social and Health NGOs'. Http://www.hse.fi/NR/rdonlyres/ D40BF349-2AE_4CF1-B75FoFoB589855AE5/6104/presenta tionAS_2+12007Skvorstova.pdf (Accessed 1 February 2009).

Sooryamoorthy, R and Gangrade, KD 2001, NGOs in India: A Cross Sectional Study, Greenwood Press, Westport.

Statistics Canada 2005, 'Cornerstones of Community: Highlights of the National Survey of Nonprofit and Voluntary Organizations', Ottawa. http:// www.ccss.jhu.edu/index.php?section = content\&view $=16$ \&sub $=91 \&$ tri $=93$ (accessed 5 March 2009$)$.

Swyngedouw, E 2005, 'Governance innovation and the citizen: the Janus face of governance beyond-the-state', Urban studies, vol. 42, pp. 1991-2006.
Vereinsstatistik 2008, Survey of the Research Institute of Sociology at Cologne University in Cooperation with V\&M Service. http:// registeronline.se/vereinsstatistik/2008/. (Accessed 1 March 2009)

Walker, JL 1991, Mobilizing Interest Groups in America. Patrons, Professions, and Social Movements, University of Michigan Press, Ann Arbor.

\section{Notes}

1. To prove their legitimacy to EU institutions, CSOs are required to adapt formal statutes and establish a transparent internal governance structure. As a result, most of the EU NGO networks now have similar organisational structures, i.e. one coordinator, one communication officer, and several policy officers. They have 'General Assemblies', where all members gather twice a year, their 'Steering Committees' make the important decisions, 'working groups' produce institutional outputs and the 'Management Committee' reviews overall organisational performance. Furthermore, they exhibit similar work methods: they all write yearly 'activity reports' to the Commission, 'disseminate' and 'publicise' their achievements through similar technologies, i.e. newspapers, web pages, conferences, toolkits, and position papers.

2. See European Commission (2004). 